\title{
Frequency of antibodies against Sarcocystis neurona and Neospora caninum in domestic cats in the state of Bahia, Brazil
}

\author{
Frequência de anticorpos contra Sarcocystis neurona e Neospora caninum em gatos \\ domésticos do Estado da Bahia, Brasil
}

\begin{abstract}
Iris Daniela Santos de Meneses ${ }^{1}$; Müller Ribeiro Andrade ${ }^{1}$; Rosângela Soares Uzêda ${ }^{1}$; Marta Vasconcelos Bittencourt ${ }^{1}$; David Scott Lindsay ${ }^{2}$; Luís Fernando Pita Gondim ${ }^{1 *}$

${ }^{1}$ Laboratório de Diagnóstico das Parasitoses Animais, Departamento de Anatomia, Patologia e Clínicas, Escola de Medicina Veterinária e Zootecnia, Universidade Federal da Bahia - UFBA, Salvador, BA, Brasil

${ }^{2}$ Department of Biomedical Sciences and Pathobiology, Center for Molecular and Infectious Diseases, Virginia-Tech, 1410 Prices Fork Road, Blacksburg, VA 24061-0342, USA
\end{abstract}

Received February 20, 2014

Accepted July 29, 2014

\begin{abstract}
Sarcocystis neurona is the major agent of equine protozoal myeloencephalitis. It infects several mammalian species in the Americas, where the definitive hosts, marsupials of the genus Didelphis (D. virginiana and D. albiventris) are found. Domestic cats are one of the confirmed intermediate hosts of the parasite; however, antibodies against $S$. neurona had never before been demonstrated in Brazilian cats. The aim of this study was to determine whether cats in Bahia, Brazil, are exposed to the parasite. A total of 272 feline serum samples (134 from feral and 138 from house cats) were subjected to an indirect fluorescent antibody test using cultured merozoites of $S$. neurona as antigen. Positivity was detected in $4.0 \%(11 / 272)$ of the tested samples, with titers ranging from 25 to 800 . The feline sera were also tested for antibodies against the protozoan Neospora caninum, with an observed antibody frequency of $2.9 \%$. To the author's knowledge, this is the first study to report antibodies against $S$. neurona in Brazilian cats. We conclude that cats are exposed to the parasite in the region of this study. Further investigations are needed to confirm the role of cats in the transmission cycle of $S$. neurona in Brazil.
\end{abstract}

Keywords: Sarcocystis neurona, Neospora caninum, feline, epidemiology.

\section{Resumo}

Sarcocystis neurona é o principal agente da mieloencefalite protozoária equina. Esse parasito infecta várias espécies de mamíferos nas Américas, onde são encontrados os hospedeiros definitivos, os marsupiais do gênero Didelphis (D. virginiana and $D$. albiventris). O gato doméstico é um dos hospedeiros intermediários do parasito. Contudo, anticorpos contra $S$. neurona ainda não tinham sido demonstrados em gatos brasileiros. O objetivo deste trabalho foi determinar se gatos da Bahia, Brasil, são expostos ao parasito. Amostras séricas de 272 felinos (134 de gatos errantes e 138 de gatos domiciliados) foram testadas pelo teste de imunofluorescência indireta, utilizando-se como antígeno, merozoítos produzidos em cultura celular. Entre as amostras testadas, 4,0\% (11/272) foram positivas com títulos entre 25 e 800. Os soros dos felinos foram também testados para anticorpos contra o protozoário Neospora caninum, cuja frequência de anticorpos foi de 2,9\%. Esse é o primeiro relato de anticorpos contra $S$. neurona em gatos brasileiros. Conclui-se que os gatos da região estudada são expostos a $S$. neurona. Estudos futuros são necessários, a fim de se confirmar o papel dos gatos no ciclo de transmissáo de $S$. neurona no Brasil.

Palavras-chave: Sarcocystis neurona, Neospora caninum, felino, epidemiologia.

\footnotetext{
*Corresponding author: Luís Fernando Pita Gondim, Departamento de Anatomia, Patologia e Clínicas, Escola de Medicina Veterinária e Zootecnia, Universidade Federal da Bahia - UFBA, Avenida Adhemar de Barros, 500, Ondina, CEP 40170-110, Salvador, BA, Brazil, e-mail: pita@ufba.br
} 


\section{Introduction}

Sarcocystis neurona is a tissue cyst-forming protozoan parasite and the main agent of equine protozoal myeloencephalitis (EPM), a serious disease that affects horses in several countries in the Americas, including Brazil (DUBEY et al., 1991; MASRI et al., 1992).

Marsupials of the genus Didelphis are definitive hosts (DH) for S. neurona; D. virginiana is the $\mathrm{DH}$ in North America (FENGER et al., 1995), and D. albiventris has been identified as a DH in South America (DUBEY et al., 2001a). Domestic cats (Felis catus) were the first intermediate hosts of $S$. neurona identified experimentally (DUBEY et al., 2000). In addition to infecting cats, the parasite may also cause disease in this animal species (DUBEY et al., 2003). Myeloencephalitis caused by $S$. neurona was reported in a cat on the third day after surgery for routine castration and onychectomy; the diagnosis was based on morphology and immunostaining of the parasite, albeit not confirmed by molecular analysis (DUBEY et al., 2003).

Infection by $S$. neurona has been confirmed in other mammalian and avian species, such as armadillos (Dasypus novemcinctus) (CHEADLE et al., 2001a), raccoons (Procyon lotor) (DUBEY et al., 2001b), sea otters (Enhydra lutris) (DUBEY et al., 2001c), skunks (Mephitis mephitis) (CHEADLE et al., 2001b) and brown-headed cow birds (Molothrus ater) (MANSFIELD et al., 2008).

Exposure of cats to $S$. neurona has been reported in North America (ROSSANO et al., 2002; TURAY et al., 2002; STANEK et al., 2003; HSU et al., 2010). Only one seroepidemiological study of $S$. neurona in cats has been conducted in Brazil; however, no positive reactions were observed among the tested animals (DUBEY et al., 2002). The aim of this study was to determine the frequency of antibodies against $S$. neurona in outdoor and indoor cats in the city of Salvador, state of Bahia, Brazil.

\section{Materials and Methods}

\section{Animals}

Blood samples were drawn from 272 cats in the city of Salvador, Bahia, between 2010 and 2011. The sample size was calculated for an infinite population, using an expected prevalence of $50 \%$, accuracy of $6 \%$ and a confidence interval of $95 \%$. The animals were divided in two groups: 134 cats were outdoor animals rescued from the streets and kept in a shelter, while 138 animals were indoor cats living with their owners, without outdoor access (Table 1). Blood samples were collected during routine clinical examination of the cats, and placed in tubes without anticoagulant. The sera were separated and stored at $-20^{\circ} \mathrm{C}$ until tested.

\section{Parasite culture and serology}

Sarcocystis neurona merozoites of the strain SN37R (SOFALY et al., 2002) were employed to screen the positive and negative samples. For titration, the SN6 (DUBEY et al.,
Table 1. Frequency of antibodies against Sarcocystis neurona and Neospora caninum tested by IFAT in sera of domestic cats from Salvador, Bahia, Brazil.

\begin{tabular}{lrc}
\hline \multirow{2}{*}{\multicolumn{1}{c}{ Animals (n) }} & \multicolumn{2}{c}{ Seropositive animals (\%) } \\
\cline { 2 - 3 } & S. neurona & N. caninum \\
\hline Indoors (138) & $3(2.17)$ & $3(2.17)$ \\
Outdoors (134) & $8(5.97)$ & $5(3.73)$ \\
Total (272) & $11(4.04)$ & $8(2.94)$ \\
\hline
\end{tabular}

1999b) and SN138 (LINDSAY et al., 2004) strains were also used, in addition to SN37R. The merozoites were maintained in CV-1 cell monolayers cultured with RPMI containing 100 units $/ \mathrm{mL}$ of penicillin, $100 \mu \mathrm{g} / \mathrm{mL}$ of streptomycin, $0.25 \mu \mathrm{g} /$ $\mathrm{mL}$ of amphotericin $\mathrm{B}$, and $5 \%$ of bovine calf serum, at $37^{\circ} \mathrm{C}$ in a $5 \% \mathrm{CO}$ atmosphere. The culture flasks were scraped when approximately $80 \%$ of the cell monolayers were infected. The cells thus removed were centrifuged at $1200 \mathrm{xg}$ for $10 \mathrm{~min}$, washed with sterile PBS pH 7.2, passed through a 26G needle, and filtered through a $5 \mu \mathrm{m}$ syringe filter.

Purified merozoites were diluted in PBS (500-1000 merozoites $/ \mu \mathrm{l}$ ) and distributed in 12-well Teflon-coated slides. The slides were dried at $37^{\circ} \mathrm{C}$ for $30 \mathrm{~min}$, fixed in methanol for $5 \mathrm{~min}$, and stored at $-20^{\circ} \mathrm{C}$ for no longer than 2 months, until analysis.

Neospora caninum (NC-Bahia strain) tachyzoites were cultured in the same way as the $S$. neurona merozoites. Vero cells were used instead of CV-1 cells, and the medium was supplemented with $5 \%$ of horse serum. The antigen purification and slide preparation methods for $N$. caninum were the same as those described above.

The IFATs for $S$. neurona and $N$. caninum were performed using serum dilutions of 1:25 and 1:50, respectively. A fluorescein isothiocyanate-labeled goat anti-cat IgG (Bethyl, Montgomery, TX, USA) was used as a secondary antibody. Positive sera were diluted 2-fold until an endpoint was reached. Negative and positive control sera for both parasites were included on each slide; these controls consisted of sera from the same tested cats that had been screened previously by IFAT.

\section{Statistical analysis}

The means of the two groups of animals (outdoor and indoor) were compared by Fisher's exact test with a 95\% confidence interval. $P<0.05$ was considered significant.

\section{Results}

Antibodies against $S$. neurona were detected in 4.0\% (11/272) of the feline sera, and $N$. caninum antibodies in $2.9 \%(8 / 272)$ of the cats (Table 1). The antibody titers for $S$. neurona were 25 (1/11), 50 (1/11), 200 (1/11), 400 (2/11), and 800 (6/11). All the cats seropositive for $N$. caninum had titers of 50 .

Seropositivity for $S$. neurona or $N$. caninum showed no significant difference between indoor and outdoor cats $(P=0.072)$. Among the 11 cats seropositive for $S$. neurona, four were also positive for $N$. caninum. 


\section{Discussion}

In this study, antibodies against $S$. neurona were detected by IFAT in domestic cats in the state of Bahia, Brazil. High antibody titers to the parasite (up to 800) were found, which is suggestive of true exposure to $S$. neurona; however, true infection by this parasite was not confirmed in these cats. To the best of our knowledge, this is the first report of $S$. neurona antibodies in Brazilian cats.

At the time this study was concluded, only one serological survey for $S$. neurona had been performed in Brazilian cats (DUBEY et al., 2002), but no seropositive animals were found. The above cited authors attributed the negative results to the fact that the tested sera came from urban cats, which probably had no contact with the parasite's sporocysts.

In the current study, the difference in seropositivity for $S$. neurona between indoor and outdoor animals was not significant $(\mathrm{P}=0.072)$; however, the number of outdoor cats seropositive for the parasite was 2.7 times higher than the number of indoor animals. Cats are intermediate hosts of $S$. neurona and may become infected after ingesting $S$. neurona sporocysts shed by opossums (DUBEY et al., 2000). Opossums also shed sporocysts of other Sarcocystis spp., including $S$. falcatula, which is closely related to $S$. neurona (MARSH et al., 1999; TANHAUSER et al., 1999). Nevertheless, the ingestion of $S$. falcatula sporocysts by cats does not seem to induce a serological cross-reaction to $S$. neurona. Cats infected experimentally with $S$. neurona sporocysts developed high antibody titers to the parasite, whereas a cat inoculated with $S$. falcatula sporocysts did not cross react against $S$. neurona (DUBEY et al., 2002).

Antibodies against $S$. neurona have been detected in North American cats, with a prevalence of exposure of up to $10 \%$ (GILLIS et al., 2003; HSU et al., 2010; ROSSANO et al., 2002; TURAY et al., 2002). In one study, serum samples from farm cats where EPM had been diagnosed previously were compared with sera from spay/neuter clinic samples (STANEK et al., 2003). Antibodies against $S$. neurona were found in $40 \%$ of the farm cats, while $10 \%$ of the samples from the spay/neuter clinic were seropositive for the parasite, suggesting that farm cats may be more commonly exposed to $S$. neurona.

In the present survey, the feline serum samples were also tested by IFAT for the closely related parasite $N$. caninum, and $2.94 \%$ (8/272) of the cats were seropositive, albeit with low antibody titers. In previous serological studies involving Brazilian cats, variable rates of exposure were reported (BRESCIANI et al., 2007; DUBEY et al., 2002), although natural $N$. caninum infections in cats have never been confirmed.

Among the $S$. neurona positive samples, four were reactive for $N$. caninum. In the same study mentioned above (DUBEY et al., 2002), 60 of 502 cats were positive for $N$. caninum antibodies, but none of the cats were seropositive to $S$. neurona. These results indicate that antibodies against $N$. caninum do not cross react with $S$. neurona antigen.

In Brazil, studies on $S$. neurona have been performed on other animal species, including horses (DUBEY et al., 1999a; HOANE et al., 2006), opossums (DUBEY et al., 2001a) and capybaras (Hydrochoerus hydrochaeris) (VALADAS et al., 2010), but no serological investigation of any confirmed intermediate host of the parasite has been reported, other than cats. Further studies are needed to confirm the role of cats as true intermediate hosts of $S$. neurona. These studies may be performed by testing whether tissues from naturally exposed (seropositive) Brazilian cats are able to induce infection in Brazilian opossums (D. albiventris) or in susceptible rodent models, such as interferon gamma knockout mice (DUBEY at al., 1999b).

\section{Conclusions}

The high titers of antibodies against $S$. neurona observed in feline sera possibly indicate exposure of the cats to the parasite in Bahia, Brazil. The low antibody titers observed for $N$. caninum do not confirm true exposure of the cats to this parasite.

\section{Acknowledgements}

This work was partially supported by FAPESB (Bahia Research Foundation). I.D.S. Meneses was the recipient of a fellowship granted by CAPES (Brazil's Federal Agency for the Support and Improvement of Higher Education), while L.F.P. Gondim was the recipient of a fellowship granted by $\mathrm{CNPq}$ (Brazil's National Council for Scientific and Technological Development).

\section{References}

Bresciani KD, Gennari SM, Serrano AC, Rodrigues AA, Ueno T, Franco LG, et al. Antibodies to Neospora caninum and Toxoplasma gondii in domestic cats from Brazil. Parasitol Res 2007; 100(2): 281-285. http:// dx.doi.org/10.1007/s00436-006-0262-4. PMid:16941188

Cheadle MA, Tanhauser SM, Dame JB, Sellon DC, Hines M, Ginn $\mathrm{PE}$, et al. The nine-banded armadillo (Dasypus novemcinctus) is an intermediate host for Sarcocystis neurona. Int J Parasitol 2001a; 31(4): 330-335. http://dx.doi.org/10.1016/S0020-7519(01)00177-1. PMid:1130611

Cheadle MA, Yowell CA, Sellon DC, Hines M, Ginn PE, Marsh AE, et al. The striped skunk (Mephitis mephitis) is an intermediate host for Sarcocystis neurona. Int J Parasitol 2001b; 31(8): 843-849. http:// dx.doi.org/10.1016/S0020-7519(01)00231-4. PMid:11403777

Dubey JP, Benson J, Larson MA. Clinical Sarcocystis neurona encephalomyelitis in a domestic cat following routine surgery. Vet Parasitol 2003; 112(4): 261-267. http://dx.doi.org/10.1016/S03044017(03)00019-0. PMid:12623205

Dubey JP, Davis SW, Speer CA, Bowman DD, de Lahunta A, Granstrom $\mathrm{DE}$, et al. Sarcocystis neurona n. sp. (Protozoa: Apicomplexa), the etiologic agent of equine protozoal myeloencephalitis. J Parasitol 1991; 77(2): 212-218. http://dx.doi.org/10.2307/3283084. PMid:1901359

Dubey JP, Kerber CE, Granstrom DE. Serologic prevalence of Sarcocystis neurona, Toxoplasma gondii, and Neospora caninum in horses in Brazil. J Am Vet Med Assoc 1999a; 215(7): 970-972. PMid:10511862.

Dubey JP, Lindsay DS, Hill D, Romand S, Thulliez P, Kwok OC, et al. Prevalence of antibodies to Neospora caninum and Sarcocystis neurona in sera of domestic cats from Brazil. J Parasitol 2002; 88(6): 1251-1252. 
http://dx.doi.org/10.1645/0022-3395(2002)088[1251:POATNC]2.0 .CO;2. PMid:12537122

Dubey JP, Lindsay DS, Kerber CE, Kasai N, Pena HF, Gennari SM, et al. First isolation of Sarcocystis neurona from the South American opossum, Didelphis albiventris, from Brazil. Vet Parasitol 2001a; 95(2-4): 295-304. http://dx.doi.org/10.1016/S0304-4017(00)00395-2. PMid:11223209

Dubey JP, Mattson DE, Speer CA, Baker RJ, Mulrooney DM, Tornquist SJ, et al. Characterization of a Sarcocystis neurona isolate (SN6) from a naturally infected horse from Oregon.J Eukaryot Microbiol 1999b; 46(5): 500-506. http://dx.doi.org/10.1111/j.1550-7408.1999.tb06067.x. PMid:10519218

Dubey JP, Saville WJ, Lindsay DS, Stich RW, Stanek JF, Speert CA, et al. Completion of the life cycle of Sarcocystis neurona. J Parasitol 2000; 86(6): 1276-1280. http://dx.doi.org/10.1645/0022-3395(2000)086[1276:CO TLCO]2.0.CO;2. PMid:11191904

Dubey JP, Saville WJ, Stanek JF, Lindsay DS, Rosenthal BM, Oglesbee MJ, et al. Sarcocystis neurona infections in raccoons (Procyon lotor): evidence for natural infection with sarcocysts, transmission of infection to opossums (Didelphis virginiana), and experimental induction of neurologic disease in raccoons. Vet Parasitol 2001b; 100(3-4): 117-129. http://dx.doi.org/10.1016/S0304-4017(01)00500-3. PMid:11698157

Dubey JR, Rosypal AC, Rosenthal BM, Thomas NJ, Lindsay DS, Stanek JF, et al. Sarcocystis neurona infections in sea otter (Enhydra lutris): evidence for natural infections with sarcocysts and transmission of infection to opossums (Didelphis virginiana). J Parasitol 2001c; 87(6): 1387-1393. http://dx.doi.org/10.1645/0022-3395(2001)087[1387:SN IISO]2.0.CO;2. PMid:11780826

Fenger CK, Granstrom DE, Langemeier JL, Stamper S, Donahue JM, Patterson JS, et al. Identification of opossums (Didelphis virginiana) as the putative definitive host of Sarcocystis neurona. J Parasitol 1995; 81(6): 916-919. http://dx.doi.org/10.2307/3284040. PMid:8544064

Gillis KD, MacKay RJ, Yowell CA, Levy JK, Greiner EC, Dame JB, et al. Naturally occurring Sarcocystis infection in domestic cats (Felis catus). Int J Parasitol 2003; 33(8): 877-883. http://dx.doi.org/10.1016/S00207519(03)00090-0. PMid:12865087

Hoane JS, Gennari SM, Dubey JP, Ribeiro MG, Borges AS, Yai LE, et al. Prevalence of Sarcocystis neurona and Neospora spp. infection in horses from Brazil based on presence of serum antibodies to parasite surface antigen. Vet Parasitol 2006; 136(2): 155-159. http://dx.doi. org/10.1016/j.vetpar.2005.10.023. PMid:16310955

Hsu V, Grant DC, Dubey JP, Zajac AM, Lindsay DS. Prevalence of antibodies to Sarcocystis neurona in cats from Virginia and Pennsylvania. J Parasitol 2010; 96(4): 800-801. http://dx.doi.org/10.1645/GE-2449.1. PMid:20476809
Lindsay DS, Mitchell SM, Vianna MC, Dubey JP. Sarcocystis neurona (Protozoa: Apicomplexa): description of oocysts, sporocysts, sporozoites, excystation, and early development. J Parasitol 2004; 90(3): 461-465. http://dx.doi.org/10.1645/GE-230R. PMid:15272465

Mansfield LS, Mehler S, Nelson K, Elsheikha HM, Murphy AJ, Knust B, et al. Brown-headed cowbirds (Molothrus ater) harbor Sarcocystis neurona and act as intermediate hosts. Vet Parasitol 2008; 153(1-2): 2443. http://dx.doi.org/10.1016/j.vetpar.2007.12.016. PMid:18342449

Marsh AE, Barr BC, Tell L, Bowman DD, Conrad PA, Ketcherside C, et al. Comparison of the internal transcribed spacer, ITS-1, from Sarcocystis falcatula isolates and Sarcocystis neurona. J Parasitol 1999; 85(4): 750-757. http://dx.doi.org/10.2307/3285758. PMid:10461964

Masri MD, Alda JL, Dubey JP. Sarcocystis neurona-associated ataxia in horses in Brazil. Vet Parasitol 1992; 44(3-4): 311-314. http://dx.doi. org/10.1016/0304-4017(92)90128-V. PMid:1466140

Rossano MG, Murphy AJ, Vrable RA, Vanzo NE, Lewis SK, Sheline $\mathrm{KD}$, et al. Cross-sectional study of serum antibodies against Sarcocystis neurona in cats tested for antibodies against Toxoplasma gondii. J Am Vet Med Assoc 2002; 221(4): 511-514. http://dx.doi.org/10.2460/ javma.2002.221.511. PMid:12184700

Sofaly CD, Reed SM, Gordon JC, Dubey JP, Ogleebee MJ, Njoku $\mathrm{CJ}$, et al. Experimental induction of equine protozoan myeloencephalitis (EPM) in the horse: effect of Sarcocystis neurona sporocyst inoculation dose on the development of clinical neurologic disease. J Parasitol 2002; 88(6): 1164-1170. http://dx.doi.org/10.1645/0022-3395(2002)088[1164:EI OEPM]2.0.CO;2. PMid:12537112

Stanek JF, Stich RW, Dubey JP, Reed SM, Njoku CJ, Lindsay DS, et al. Epidemiology of Sarcocystis neurona infections in domestic cats (Felis domesticus) and its association with equine protozoal myeloencephalitis (EPM) case farms and feral cats from a mobile spay and neuter clinic. Vet Parasitol 2003; 117(4): 239-249. http://dx.doi.org/10.1016/j. vetpar.2003.09.002. PMid:14637026

Tanhauser SM, Yowell CA, Cutler TJ, Greiner EC, MacKay RJ, Dame JB. Multiple DNA markers differentiate Sarcocystis neurona and Sarcocystis falcatula. J Parasitol 1999; 85(2): 221-228. http://dx.doi. org/10.2307/3285623. PMid:10219299

Turay HO, Barr BC, Caldwell A, Branson KR, Cockrell MK, Marsh AE. Sarcocystis neurona reacting antibodies in Missouri feral domestic cats (Felis domesticus) and their role as an intermediate host. Parasitol Res 2002; 88(1): 38-43. PMid:11826870.

Valadas S, Gennari SM, Yai LE, Rosypal AC, Lindsay DS. Prevalence of antibodies to Trypanosoma cruzi, Leishmania infantum, Encephalitozoon cuniculi, Sarcocystis neurona, and Neospora caninum in Capybara, Hydrochoerus hydrochaeris, from São Paulo State, Brazil. J Parasitol 2010; 96(3): 521-524. http://dx.doi.org/10.1645/GE-2368.1. PMid:20020808 